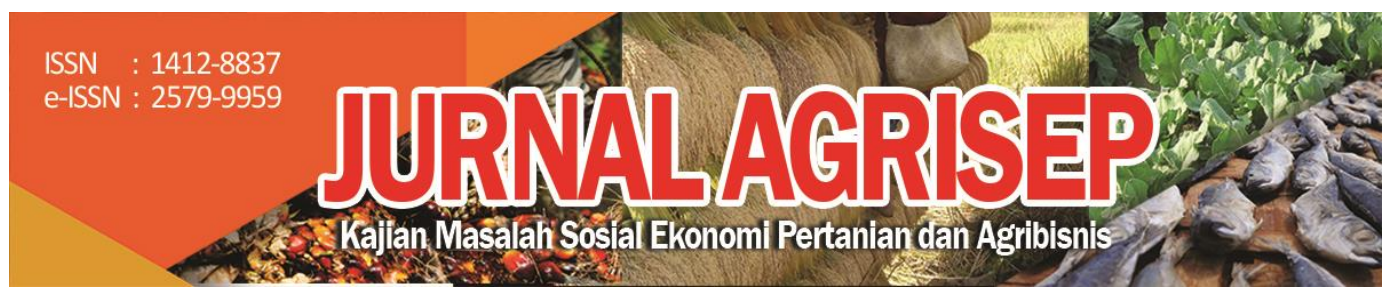

DOI: 10.31186/jagrisep.19.2.447-461

\title{
APPLYING THE COMPETITIVENESS ANALYSIS FOR HORTICULTURAL COMMODITY PROSPECT IN PALEMBANG PERI-URBAN AREA, INDONESIA: CALIFORNIA PAPAYA (Caricia Papaya L.) CASES
}

\author{
Dessy Adriani 1) \\ 1),2)Researcher/Lecturer in Agribusiness Study Program Faculty of \\ Agriculture Universitas Sriwijaya \\ Email: dessyadriani@fp.unsri.ac.id
}

\begin{abstract}
This research aimed to analysis the competitive advantage, comparative advantage, and government policy impact to the prospect of California Papaya horticultural commodity in peri-urban area. This research conducted in Talang Jambe Village of Sukarami Sub-district in Palembang on March 2017. Research location was selected by considering that Talang Jambe Village is central producer for California Papaya in Palembang. Sampling method were simple random sampling. Data analysed by using Policy Analysis Matrix (PAM). Research result showed that prospect of California Papaya horticultural commodity in peri-urban area had competitive advantage from Private Profitability and PCR. California Papaya horticultural commodity had also comparative advantage social profitability and DRC. Government policy impact were profitable for California Papaya producer and consumer as well. The existence of government intervention on the output against the farming more profitable consumers because consumers buy lower price than the actual price. In other words the transfer of surplus occurs from the producers to the consumers and the farmers ' acceptance of output reduction occurred as the existence of government policy intervention. In other words it indicate that there is a government policy that caused the private price is less than the social price. California Papaya horticultural commodity in peri-urban area only received $63 \%$ of the price the price that is supposed to received.
\end{abstract}

Keywords: California Papaya, Competitiveness, Horticulture, Peri-urban, Prospect 


\begin{abstract}
ABSTRAK
Penelitian ini bertujuan untuk menganalisis keunggulan kompetitif, keunggulan komparatif, dandampak kebijakan pemerintah terhadap prospek komoditas hortikultura Pepaya California di kawasan kota. Penelitian ini dilakukan di Desa Talang Jambe Kecamatan Sukarami Kota Palembang pada bulan Maret 2017. Lokasi penelitian dipilih dengan pertmbangan bahwa Desa Talang Jambe merupakan sentra penghasil Pepaya California di Palembang. Metode pengambilan sampel adalah simple random sampling. Data dianalisis dengan menggunakan Policy Analysis Matrix (PAM). Hasil penelitian bahwa prospek komoditas hortikultura Pepaya California di kawasan pinggiran kota memiliki keunggulan kompetitif dari Privat Provitability dan PCR. Komoditas hortikultura Pepaya California juga memiliki keunggulan komparatif provitabilitas social dan DRC. Dampak kebijakan pemerintah juga menguntungkan bagi produsen dan konsumen Pepaya California, Adanya intervensi pemerintah terhadap output usahatani lebih menguntungakn konsumen karena konsumen membeli dengan harga lebih rendah dari harga sebenarnya. Dengan kata lain, terjadi perpindahan surplus dari produsen ke konsumen dan penerimaan petani terhadap penuruan output terjadi karena adanya ntervensi kebijakan pemerntah. Dengan kata lain hal ini mengindikasikan adanya kebijakan pemerintah yang menyebabkan private price lebih rendah dari pada social price. Komoditas hortikultura Pepaya California di daerah pinggiran kota hanya menerima $63 \%$ dari harga yang seharusnya diterima.
\end{abstract}

Kata kunci: Daya Saing, Hortikultura, Pepaya California, Prospek, Pinggiran Kota

\title{
INTRODUCTION
}

Urban and peri-urban horticulture (UPH) helps to grow greener cities by contributing to food security, employment, waste management and community well being. Urban horticulture, as plant production activities, is conducted in a city or suburb that produce horticultural plants that are wholly or partially edible, economically viable and has the potential to reduce emissions. Moreover, to increase productivity in limited resource areas, the urban and peri urban area are considered more advantageous than open systems (i.e. Villages). The production and daily delivery to market of perishable horticultural crops from smallholder farmers close to large urban centers (peri-urban horticulture; market gardening) have been important for millennia. Horticultures, vegetables, fruits, medicinal and also aromatic plants is delivered directly to urban consumers with little or no oversight for quality or safety (Surakshitha. N. C, Kumar M and V. Kumar, 2012).

In other side, horticultural sector is one of the fast growing sector of agriculture in Indonesia. While in the vegetable, horticulture is one source of vitamins and minerals. According to Permana (2003), horticulture is one of the commodities that are potential to be developed especially in urban and periurban because the horticulture mainly fruit are a source of economic growth in 
addition to being able to show the development of export business. Not only for the provision of food, provision of industrial raw material, but also able to increase the income of farmers who provide jobs for the people of indonesia.

Papaya (Carica papaya l.) is one of the fruits that also grow fastly in periurban area. Papaya fruit belongs to the popular fruit and favored by most of the world's population. This is because the fruit is tender meat with red or yellow, sweet and refreshing as well as many contain water. Papaya is a plant annuals so that this fruit can be available any time (Barus and Shukri, 2008). One type of papaya that began to bloom cultivated is a Calina Papaya or California Papaya.

California Papaya has a higher price than other papaya prices. California Papaya has the advantage of fruit is not too large with a size between 0.8-2 $\mathrm{kg} /$ fruit, thick-skinned, oval-shaped, yellow ripe fruit, sweet taste and thick fruit flesh. California Papaya is a superior type with a shorter age than other types of papaya. The stem is shorter than other types of papaya that is about 2 meters and the fruit can be harvested after the age of 7 to 9 months. Trees can bear until the age of 4 years with good fruit production capability if treated properly. In 1 month can be harvested up to 4 times. Once harvested, California papaya trees can produce 10 to 20 pieces. With one harvest per week can reach 2 tons per hectare (Epetani, 2015).

California Papaya has the advantage of fruit is more sweet, durable, and can be harvested faster than other papaya varieties. California Papaya is very potential if cultivated intensively, because it is able to bear fruit all the time without knowing the season. Papaya California can be harvested when visible signs that there is a yellow tinge in the main papaya fruit on the fruit tip (Darmayuda, 2014).

According to Permana (2007), the ability of the competitiveness of producers to produce a commodity with a good quality and perfect humility so that production costs at price levels that occurred in the market, farmers can gain and maintain the continuance of its production. California Papaya horticultural commodity will not be separated from policy - government policies that affect the competitiveness of the commodity. Policies that lower input costs would result in a value in order to increase output and also improve the competitiveness of the commodity, while a policy of raising input costs will lead to decrease in value to output and will also lose competitiveness.

To penetrate international market, we have to develop competitiveness of products (Goerge et al., 2010; Kuma et al., 2013). Although we realize that to improve the competitiveness of agricultural commodities is very difficult, in which Indonesia should be able to face international competition that has driven the economy competitive and comparative will hopefully be able to improve the competitiveness of the Indonesian fruit commodities in international markets in addition to increase in human resources (farmers), 
improve to the technology, as well as government policies in favour of farmers (Monke, E.A., and S.R, Pearson. 1989; Yao, 1997; Permana, 2007; Haryanto, 2018).

Sukmawati et al., (2014) stated that in supporting papaya development as a competitive local superior commodity, it needs to be done some efforts are as follows: (1) increase a skillful worker; (2) improve business management; (3) increase papaya productivity by using technology and study papaya planted technology in specific local superior commodity; (4) develop the involvement of the business relation; (5) provide market information and information technology network; and (6) improve infrastructures. The most important thing that California papaya can grow in urban, rural and also peri-urban. Palembang is one of area that cultivated California papaya, especially in periurban area. There are current plantation of papaya in the three districts of Palembang, that is Sukarami, Sako and Sematang Borang, reaches 74 hectares with an average production of 36 tons per acre per year. Until now there has not been much research on competitive and comparative advantages of papaya, especially in peri-urban locations. The purpose of this research are: (1) Analysing the competitiveness of California papaya agribusiness in peri-urban area on the basis of competitive advantage and comparative advantage, and (2) Analysing the impact of government policies against input-output price to California papaya agribusiness in Palembang peri-urban area.

\section{RESEARCH METHOD}

This research was carried out in Talang Jambe Village Sub-district Sukarami Palembang. Site selection is done by the consideration that Jambe Village has the biggest production center of papaya in Palembang. Talang Jambe Village in Sukarami district is areas that become food self-sufficient integrated pilot village. Papaya is the most prominent plant in Talang Jambe village. Research methods were survey research methods. Sampling method is simple random method that means that all existing papaya farmer in Village Talang Jambe gaining equal opportunity to be selected into the sample. Papaya farmer in Talang Jambe totalled 52 KK with selected 30 samples taken (Respondent rate 57,69\%).

To answer the goal research, the comparative and competitive advantage, and also the impact of the Government's policy is using the Policy Analysis Matrix (PAM). It is done thoroughly and systematically. The data presented in tabulated form using Microsoft excel program and explained in the descriptive. Analysis of the competitiveness of this California Papaya based on few stages as follows: 1) The determination of input farming. In this case the input is categorized as materials, equipment and manpower in its use requires a fee; 2 ) Grouping input into Tradable inputs (input being traded on international 
markets) and non tradable input (inputs are produced domestically; 3) Determined private and social price.

The data presented in the form of descriptive tabulations are then entered in the calculation of PAM on Table 1

Table 1. Policy Analysis Matrix

\begin{tabular}{lccccc}
\hline \multirow{2}{*}{ Description } & Revenue & \multicolumn{3}{c}{ Input Costs } & \multirow{2}{*}{ Benefit } \\
\cline { 3 - 4 } & (Output) & Tradable & Non Tradable nn & \\
\hline Private Price & $\mathrm{A}$ & $\mathrm{B}$ & $\mathrm{C}$ & $\mathrm{D}=\mathrm{A}-(\mathrm{B}+\mathrm{C})$ \\
Social Price & $\mathrm{E}$ & $\mathrm{F}$ & $\mathrm{G}$ & $\mathrm{H}=\mathrm{E}-(\mathrm{F}+\mathrm{G})$ \\
Divergence Effect & $\mathrm{I}=\mathrm{A}-\mathrm{E}$ & $\mathrm{J}=\mathrm{B}-\mathrm{F}$ & $\mathrm{K}=\mathrm{C}-\mathrm{G}$ & $\mathrm{L}=\mathrm{D}-\mathrm{H}=\mathrm{I}-\mathrm{J}-\mathrm{K}$ \\
\hline
\end{tabular}

Source: Monke and Pearson, (1989)

Note:

1) Private Price Line: $\mathrm{A}=$ Private Revenue $=($ Output Price $\mathrm{x}$ Production $) ; \mathrm{B}=$ Private Cost Input Tradable; $C=$ Private Cost Domestic Input; $D=$ Private Profits = A - B - C (Private Benefit);

2) Social Price Line: $\mathrm{E}=$ Social Revenue $=$ (Social Price $\mathrm{x}$ Production); $\mathrm{F}=$ Social Cost Input Tradable; $\mathrm{G}=$ Social Cost Domestic Input; $\mathrm{H}=$ Social Benefits $=\mathrm{E}-\mathrm{F}-\mathrm{G}$;

3) Divergence Effect Line: I = Net Transfer $=$ A - E; J = Transfer of Tradable Inputs $=\mathrm{B}-\mathrm{F} ; \mathrm{K}=$ Transfer of Non tradable Inputs/ domestic factor transfer $=\mathrm{C}-\mathrm{G} ; \mathrm{L}=$ Net Transfer $=\mathrm{I}-\mathrm{J}-\mathrm{K}$.

The competitiveness is reflected by the range of value, whether highly competitive, high, medium, low or very low.These criteria are presented in Table 2.

Table 2. Competitiveness Criteria

\begin{tabular}{lccccc}
\hline \multicolumn{1}{c}{ Indicator } & & \multicolumn{5}{c}{ Criteria } \\
\hline Private Profitability & + & - & - & - & - \\
Social Profitability & + & + & - & - & - \\
Private cost Ratio & + & + & + & - & - \\
Domestic Cost Ratio & + & + & + & + & - \\
\hline Total Value & $4+$ & $3+1-$ & $2+2-$ & $1+3-$ & $4-$ \\
\hline Competitiveness & Very high & High & Neutral & Low & Very Low \\
\hline
\end{tabular}

Source: Kohari, et al., 2005 


\section{RESEARCH RESULTS}

\section{Respondent Characteristics}

Carica papaya L., is one of the main fruit crops cultivated in the tropical and sub-tropical zones. Initially Papaya was mainly planted (> 90\%) and consumed in developing countries, but papaya quickly became an internationally important fruit, both as fresh fruit and as a processed product. From an agronomic point of view, papaya grows best under conditions of drainage, aeration, and rich organic matter, $\mathrm{pH}$ 5.5-6.7 (Teixeira et al., 2007).

Table 3. Respondent Characteristics

\begin{tabular}{cccc}
\hline No & \multicolumn{1}{c}{ Characteristics } & Number of Samples & Percentage (\%) \\
\hline 1 & Age (Years) & 10 & \\
& $34-44$ & 14 & 33.33 \\
& $45-56$ & 6 & 46.66 \\
& $57-69$ & 30 & 100.00 \\
& Total & & \\
\hline 2 & Land Area (Ha) & 9 & 30.00 \\
& $0.1-0.25$ & 15 & 50.00 \\
& $0.3-0.45$ & 6 & 20.00 \\
& $0.5-0.65$ & 30 & 100.00 \\
& Total & & \\
3 & Education & 7 & 23,33 \\
& Elementry School & 8 & 26,66 \\
& Yunior High School & 15 & 50,00 \\
& Senior High School & 30 & 100.00 \\
\hline Total & & \\
4 & Family Numbers (People) & 9 & 30,00 \\
& $1-3$ & 19 & 63,33 \\
& $4-6$ & 2 & 6,66 \\
& $7-9$ & 30 & 100,00 \\
\hline
\end{tabular}

Source: primary data, 2018

The age of the sample farmers obtained in this study varied with an average age of 49 years, amounting to $46 \%$ of farmers aged between $45-56$ years. The education of farmers who seek papaya farming in rural areas by $50 \%$ is Senior High School. The land scale for papaya farming ranges from 0.10 to $0.65 \mathrm{Ha}$, as many as $50 \%$ of farmers own land between $0.30-0.45 \mathrm{Ha}$. Farmers who have a family of between $4-6$ people range from $63.33 \%$ as seen on Table 1 .

452 | Dessy Andriani, Idham Alamsyah; Applying The Competitiveness Ana ... 
Characteristics of respondents indicate that farmers who implement papaya farming in pery-urban are dominated by young people, high school education, and the number of family members more than 2 . This result is a positive sign of the entry of millennial generation into the agricultural sector. The reason why they chose to do business in suburban areas was because of the reason to bring the production area closer to the market. This is done, not only cause of shortening marketing costs, but also prevent crop damage due to the long marketing chain.

\section{Cost structure, Revenue and Benefit of California Papaya in Peri-Urban Farming}

In PAM analysis, production costs are divided into three groups: tradable and non tradable inputs and domestic factors as shown in Table 4.

Table 4. Cost structure, Revenue and Benefit of California Papaya in PeriUrban Farming

\begin{tabular}{lrrrc}
\hline \multirow{2}{*}{ Cost structure } & \multicolumn{2}{c}{ Private } & Social \\
\cline { 2 - 5 } & Value (Rp) & Percentage (\%) & Value (Rp) & Percentage (\%) \\
\hline 1. Input Tradable & & & & \\
$\quad$ Non Organic Fertilizer & $1,320,700$ & 8.56 & $2,112,320$ & 12.97 \\
Sub-total & $1,320,700$ & & $2,112,320$ & \\
2. Input Non Tradable & & & 246,500 & 1.51 \\
$\quad$ Seed & 174,000 & 1.12 & 440,000 & 2.70 \\
$\quad$ Liquid Organic Fertilizer & 440,000 & 2.85 & 485,967 & 2.98 \\
$\quad$ Solid Organic Fertilizer & 485,967 & 3.15 & $9,380,000$ & 57.61 \\
$\quad$ Manure & $9,380,000$ & 60.80 & & 10.00 \\
3. Domestic Factor Total & & & $1,628,680$ & 10.44 \\
$\quad$ Labor & $1,628,680$ & 10.56 & $1,700,000$ & 1.76 \\
$\quad$ Land Rent & $1,700,000$ & 11.00 & 287,448 & \\
$\quad$ Traditional Equipment & 287,448 & 1.86 & $14,168,635$ & \\
Sub-Total & $14,096,095$ & & $16,280,955$ & 100.00 \\
\hline Total Cost & $15,416,795$ & 100.00 & $127,335,528$ & \\
\hline Revenue & $80,692,692$ & & $111,054,573$ & \\
Benefit & $65,275,897$ & &
\end{tabular}

Source: primary data, 2018

Calculation of california papaya in Peri-Urban Farming cost structure is done to see the level of profit obtained. From these calculations will be obtained the largest percentage of cost and how much benefit obtained from each cost incurred. 


\section{Advantages Analysis}

The competitiveness in the California Papaya in Peri-Urban Farming is shown in Table 5. The output value, production costs and other cost then calculated into financial and economic analysis, further allocated into tradable and non-tradable.

Private Profitability $(\mathrm{D})$, which is $\mathrm{D}=\mathrm{A}-(\mathrm{B}+\mathrm{C})$ or the private benefit obtained from the results of a difference between the value of revenue (A) with the price of tradable (B) and non-tradable (C) for privat input. California Papaya private profit in Peri-Urban Farming amounting to Rp. 65,275,897 obtained by using the actual price or the present market price of farmers. With reference to the PP $>0$, then papaya production system obtains a actual profit above the normal profit, it means that farming that deserves to be continued. In other words, the review of private profitability of California Papaya in Peri-Urban Farming in peri-urban area have competitiveness.

Social Profitability $(\mathrm{H})$, which is $\mathrm{H}=\mathrm{E}-(\mathrm{F}+\mathrm{G})$ or the social benefits obtained from the results of a difference between the value of revenue (E) with the social price of tradable $(\mathrm{F})$ and non-tradable $(\mathrm{G})$ social input. The value of social profitability earned $\mathrm{Rp} 111,054,573$. The criteria, if SP $>0$ then papaya production system has been running efficiently and also has a comparative advantage, so worthy to be developed. This research finding was similar with Yao (1997) that stated Crop Farming had a comparative advantage in Thai Agriculture.

Table 5. Policy Analysis Matrix (PAM) of California Papaya in Peri-Urban Farming

\begin{tabular}{|c|c|c|c|c|}
\hline \multirow{2}{*}{ Description } & \multirow{2}{*}{$\begin{array}{l}\text { Revenue (Output) } \\
\text { (Rp/Ha/Season) }\end{array}$} & \multicolumn{2}{|c|}{ Input Cost $(R p)$} & \multirow{2}{*}{ Benefit $(R p)$} \\
\hline & & Tradable & Non tradable & \\
\hline Private Price & $80,692,692$ & $1,320,700$ & $14,096,095$ & $65,275,897$ \\
\hline Social price & $127,335,528$ & $2,112,320$ & $14,168,635$ & $111,054,573$ \\
\hline Divergence Effect & $-46,642,836$ & $-791,620$ & $-72,540$ & $-45,778,676$ \\
\hline
\end{tabular}

Source: primary data, 2018

\section{The Analysis of Financial and Economic Efficiency}

The private Cost Ratio (PCR) obtained from $\mathrm{PCR}=\mathrm{C} /(\mathrm{A}-\mathrm{B})$ (ratio) can be seen in Table 5. Based on Table 6, obtained PCR of 0.17. Referring to the criteria of the private cost ratio equal to 1 and fewer, then the commodity system is capable of financing its domestic factors on the ability and private price increasing. The value of PCR is an indicator of competitive advantage a commodity. This ability makes it clear that the existence of farming in California papaya has also a competitive advantage. 
Table 6. The Value of The Parameters Competitive And Comparative Advantages of California Papaya in Peri-Urban Farming

\begin{tabular}{|c|c|c|}
\hline No & Parameters & Value \\
\hline 1 & Private Cost Ratio (PCR) & 0.17 \\
\hline 2 & Domestic Resources Cost Ratio (DRC) & 0.13 \\
\hline
\end{tabular}

Source: primary data, 2018

Domestic Resource Cost Ratio is DRC = G/(E-F). Domestic Resource Cost Ratio (DRC) or social benefits obtained from the results of the ratio values of the social costs of non tradable inputs $(\mathrm{G})$ and the difference of revenue (E) with the social cost of tradable inputs $(\mathrm{F})$. The value of the DRC gained 0.13 . It means the commodity system increasingly efficient and have competitiveness in the world market so that votes have a greater export opportunities. In conclusion can be explained that California papaya in Peri-Urban Farming have competitiveness both in the comparative and competitive advantage. The estimates of DRC revealed that the Peri-Urban Farming had a comparative advantage in California Papaya production (DRC was below one). The level of DRC shows that the value of domestic resources used in producing 1 ha of California Papaya in Peri-Urban Farming was less than the cost of its import. DRC level decreased in the post liberalization period, which reveals an improvement in the comparative advantage of agriculture production in recent years (Reddy et al., 2008; Kanaka and M. Chinnadurai, 2013).

\section{The Impact Of Government Policy}

Every developing country has government policy in the agricultural sector so that it can determine the success of the development efforts and in order to increase the country's export. A policy in economic activities can provide a positive impact or negative towards the economy. So that the impact of the policy can also decrease or increase production or productivity of an economic activity. Another goal of government policy in the trade is usually to protect domestic farming. From PAM analysis, we can describe the impact of government policy to California papaya in Peri-Urban Farming.

\section{Output Policy}

Government policy (in the form of subsidies or tax) on a commodity agribusiness can effect positive or negative. Indicators of the impact of government policy towards the output can be viewed by using the value OT (Transfer Output) and NPCO (Nominal Protection's on Output). Output transfer is the difference between the calculated on revenue of the price financially with the revenue that calculated at the shadow price. A positive value of the output transfer shows the magnitude of the 
intensive community (consumers) against the farming. In other words the community buy the commodity is higher than the price that should be paid. However, if the value of the output transfer is negative means that consumers buy the commodity at a price that is lower than the actual price. The result can be seen in Table 7 .

Table 7. Output Transfer and Nominal Protection's on Tradable Output of California Papaya in Peri-Urban Farming

\begin{tabular}{clr}
\hline No & \multicolumn{1}{c}{ Parameters } & \multicolumn{1}{c}{ Value } \\
\hline 1 & Output Transfer $(\mathrm{OT})$ & $-46,642,836.00$ \\
2 & Nominal protection coefficient on tradable output & 0.63 \\
\hline
\end{tabular}

Source: primary data, 2018

Based on Table 7, the output transfer, I = A-E obtained from the results of the subtraction between the revenue of the output on the private price (A) with the output on the social price (E). Output transfer result in negative $\mathrm{Rp}-46,642,836$. The criteria, if the value is 0 or fewer, means that private price of papaya california are lower than social price. This condition indicates that the existence of government intervention on the output against the farming more profitable consumers because consumers buy lower price than the actual price. In other words the transfer of surplus occurs from the farmers to the consumer. While farmers themselves feel better there is no intervention from the government such as tax charged to them, the increase in fuel prices which affect the cost of transfortation due to the intervention made by the government led to the farmer is not able to accept the price of private (private price) is the same as the price of social (shadow price) or at least approaching the social price.

The nominal protections on tradable output $(\mathrm{NPCO}=\mathrm{A} / \mathrm{E})$ obtained from the results of division between private prices output on revenue (A) with the output on the social price (E). NPCO results 0.63 , it's indicated government policy caused the private price, which is less than the social price. Farmer of papaya only received $63 \%$ of the price the price that is supposed to receive.

\section{Inputs Policy}

Government policy does not only impact to the price of output but impact also to the prices of inputs. The form of the government's policy against such input subsidies or trade barriers are applied with the hope that farmers can leverage resources optimally and can protect domestic resources (Indriyati, 2007). Indicators used to analyse government intervention against production inputs is the value of the Input Transfers

456 | Dessy Andriani, Idham Alamsyah; Applying The Competitiveness Ana ... 
(IT), Transfer Factor (TF) and Nominal protection coefficient on tradable input (NPCI) as seen on Table 8.

Table 8. Input Transfer, Nominal Protection's on Tradable Inputs and Transfer Factor of California Papaya in Peri-Urban Farming

\begin{tabular}{clr}
\hline No & \multicolumn{1}{c}{ Parameters } & \multicolumn{1}{c}{ Value } \\
\hline 1 & Input Transfer & $-791,620.00$ \\
2 & Nominal protection coefficient on tradable input & 0.63 \\
3 & Factor transfer & $-72,540.00$ \\
\hline
\end{tabular}

Source: primary data, 2018

Input Transfer (IT) obtained negative 791,620 with the criteria, if IT 0 indicates < government subsidies to the tradable inputs so that farmers do not pay the full social costs that should have been paid. The subsidies policy given by the government is favourable to the farmers because it means the cost of production becomes reduced. Reduced production costs for this causes impact getting bigger of benefit.

The nominal obtained 0.63 , if it is $<1$ then the farmers receive tradable inputs over subsidies, so that the farmers can buy tradable inputs with lower prices. It also shows that the policy provide incentives to farmers in the form of input price of papaya that paid farmers only 62 percent of the input price should (farmers get government subsidies), which are reflected from the coefficient of 0.63 . Transfer Factor obtained amounted to negative 72,540 this indicates if the FT $<0$ means there are government policies that protect the domestic input producers by granting subsidies.

\section{Input-Output Policy}

The Government's policy analysis on input-output is a combination between input and output policy. The impact of the overall policy to the input or output can be seen from the effective Protection Coefficient (EPC), Net Trasfer (NT), Profitability coefficient (PC) and Subsidy Ratio to producer (SRP) in Table 9. EPC gained 0.63 criteria, EPC $<1$ means the policy does not run effectively or government policy is currently lacking support or protect the farmers of papaya. This happens on the Government's policy of trading of papaya so that farmers have not been able to accept the price of papaya as a social price, this caused the chain marketing papaya to hitchhiking farmer, and farmer himself was not yet able to sell directly to wholesalers at the district level especially for directly to other areas. Marketing issues are common problems faced by agricultural products. The issue of inefficiency colors the agricultural commodity market as also revealed in research results Rahayu et al., (2020). 
Net transfer is $-45,776,216$. With the criteria NT $<0$ indicates no additional surplus in farming due to government policies that are applied to the inputs and outputs. This means has not seen the existence of economic incentives for increases the papaya production so the surplus in farming reduced.

Table 9. Value of Parameters Input-Output Policy of California Papaya in Peri-Urban Farming

\begin{tabular}{clr}
\hline No & \multicolumn{1}{c}{ Parameters } & \multicolumn{1}{c}{ Value } \\
\hline 1 & Effective protection coefficient & 0.63 \\
2 & Net transfer & $-45,776,216$ \\
3 & Profitability coefficient & 0.58 \\
4 & Subsidy ratio to producer & -0.35 \\
\hline
\end{tabular}

Source: primary data, 2018

Profitability coefficients obtained 0.55 criteria. With the criteria PC $<1$ then government policy resulted in an acceptable profit producers or farmers smaller than without any policy. This means that the profit of this California Papaya horticultural commodity in peri-urban area if there is influence of the intervention of the Government of the social advantage of 0.55 . Producers received only 55 percent of the profits farming if the government does not intervene.

Subsidy ratio are obtained -0.35 . With the criteria, if SRP $<1$ showed that policy government as long as it leads to the producers or farmers papaya production costs are greater than social costs. Beside that, it's also important for develop government policies in order to shorten the chain of marketing so that it can increase the selling price of the private, its impact on increasing the acceptance rate of private farmers and farmer's profitability that it's relevant with Kalaba (2012).

\section{Assessment of the Competitiveness Results}

The ability of competitiveness is reflected by the range of commodities, including competitiveness are very high, high, medium, low or very low. These criteria are presented in Table 10. Based on Table 10. the competitiveness in California Papaya agribussiness in peri-urban has very high competitiveness. It can be priority to be developed. This is apparent from the fourth parameter value i.e., PP, PS, PCR, DRC is positive meaning that Farming has a competitive advantage and comparative as well as it deserves to be developed. Almost all the result in this research are relevant with Ramon E. G., R.G. Alvarez, H.A.J. Pohlan, J.C.A. Rivero, J.P. Fernandez and V. Geissen (2008); and Haryanto (2018).

458 | Dessy Andriani, Idham Alamsyah; Applying The Competitiveness Ana ... 
The results of this study are also in line with the research of Sukmawani et al. (2014a); Sukmawani et al., (2014b), Which shows that papaya has comparative and competitive advantages based on LQ values, superior criteria and competitiveness (PCR and DRCR). Papaya is a basic commodity, has a comparative advantage, and the results can not only meet the needs in Sukabumi Regency, but can also be sent outside the Sukabumi Regency area.

Table 10. Assessment of The Competitiveness Results of California Papaya in Peri-Urban Farming

\begin{tabular}{lccccc}
\hline \multicolumn{1}{c}{ Indicator } & Values & \multicolumn{4}{c}{ Criterion } \\
\hline PP & 65.275 .897 & - & - & - & - \\
PS & 111.054 .573 & + & - & - & - \\
PCR & $0,17(<1)$ & + & + & - & - \\
DRC & $0,13(<1)$ & + & + & + & - \\
\hline Total Value & $4+$ & $3+1-$ & $2+2-$ & $1+3-$ & $4-$ \\
\hline Competitiveness Level & Very high & High & Medium & Low & Very Low \\
\hline
\end{tabular}

Source: primary data,2018

\section{CONCLUSION AND POLICY IMPLICATION}

\section{Conclusion}

California Papaya Agribussiness has a competitive and a comparative advantage. The commodity system more efficient and to have competitiveness in the world market so that it has a greater export opportunities.

Private price lower than the social price of papaya. This condition indicates that the existence of government intervention on the output against the farming more profitable consumers because consumers buy in lower price than the actual price. In other words the transfer of surplus occurs from the producers to the consumers and the farmers' acceptance of output reduction occurred as the existence of taxes. In other words it indicate that there is a government policy that caused the private price is less than the social price. Farming of California papaya only received $63 \%$ of the price the price that is supposed to received.

Government's subsidy towards the tradable inputs so that farmers do not pay the full social costs that should have been paid. Then farmers receive subsidies on top of tradable inputs, so that farmers can buy tradable inputs with lower prices

Papaya farmers have not been able to accept the price of papaya as a social price, this caused the chain marketing papaya to hitchhiking farmer, and farmer himself was not yet able to sell directly to wholesalers at the district 
level especially for directly to other areas. The impact of government policy is not running effectively or the government policy is less support or protects papaya farmers.

\section{Policy Implication}

The analysis shows that fertilizer subsidies help increase farmers' social profit. Therefore, input subsidies for papaya farming should be carried out to support farmers' income. Improvement of marketing institutions needs to be done so that farmers can sell directly to consumers. In this way, private profits can increase, because farmers receive private prices of papaya equal to their social prices.

To open the papaya export market, it is necessary to have full guidance of the government related to fulfilling the physical and administrative requirements of the papaya commodity which will be exported

\section{REFERENCES}

Barus, A., and Syukri. 2008. Agroteknologi Tanaman Buah-buahan. USU Press. Medan.

Darmayuda. 2014. Papaya California. www.cybex.pertanian.go.id. Accessed at $18^{\text {th }}$ April 2019.

Epetani. 2015. Cara Budidaya Pepaya California. http://epetani.pertanian.go.id. Accessed at $1^{\text {st }}$ April 2019.

Goerge, Galanos dan Giannis Manasis. 2010. Analysis of Competitiveness Of Greek's Olive Oil Sector Using Porter's Diamond Model. Research Journal of International Studies-Issues. 16 (04): 33-46.

Haryanto, Lorenta In, Masyhuri, and Irham. 2018. The Policy Analysis Matrix in Measuring Competitiveness of Maize Farming System in Marginal Areas . Jurnal Agro Ekonomi. 29 (12): 244-260 .

Kanaka and M. Chinnadurai. 2013. The Policy Analysis Matrix Of Rice Cultivation In India. European Journal of Physical and Agricultural Sciences. 1(1): 8-19.

Kalaba, Y. 2012. Analisis Daya Saing Kakao Indonesia. Program Pascasarjana Fakultas Pertanian. Universitas Gajah Mada. Yogyakarta. Disertasion (Unpublished).

Kalaba, Y. 2012. Analisis Daya Saing Kakao Indonesia. Program Pascasarjana Fakultas Pertanian. Universitas Gajah Mada. Yogyakarta. Disertasion (Unpublished).

Kohari, K., Ma'sum, M. dan Widiastuti, D. 2005. Dampak Kebijakan dan Pemasaran terhadap Daya Saing Usahatani Kentang di Kecamatan Kejajar Kabupaten Wonosobo. Research Report Agriculture Faculty UNSOED. Purwokerto. (Unpublished) 
Kuma Berhanu, Abebe, Chindi, Shenkut Ayele, Gebremedhin Woldegiorgis, Yohanner Lemma and Shiferaw Tafesse. 2013. Role of Farmer Field School And Farmer Research Group in Bringing Attitudinal And Knowledge Change: The Case of Integrated Potato Disease and Nutrient Management in Ethiopia. Asian Journal of Rural Development. 3 (1) :1-13.

Monke, E.A., dan S.R, Pearson. 1989. The Policy Analysis Matrix for Agricultural Development. Cornell University Press. London

Permana, L. 2007. Analisis Daya Saing Buah Pepaya (Carica papaya L): Kasus di Desa Nagrak Kecamatan Sukaraja dan di Desa Pasirgaok Kecamatan Rancabungur, Bogor, Jawa Barat. Skripsi. Institut Pertanian Bogor. Bogor. (Unpublished)

Rahayu,Wiwit., Barokah, Umi., and R. U.Fajarningsih. 2020. Strategi Pengembangan Usahatani Jagung Pada Lahan Kering Di Kabupaten Wonosobo. AGRISEP. 19 (1): 207 - 218

Ramon E. G., R.G. Alvarez, H.A.J. Pohlan, J.C.A. Rivero, J.P. Fernandez and V. Geissen. 2008. Comparisons of Production Costs and Profit of Three Different Technology Levels of Papaya Production in Tabasco, Mexico. Journal of Agriculture and Rural Development in the Tropics and Subtropics. 109 (1): 1-14.

Reddy, B. D. R., Lalith Achoth And B. V. Chenappa Reddy. 1998. Export Competitiveness of Groundnut Empirical Evidence from Karnataka. Astha Vijnana. 15 (3): 263-270

Sukmawani Reny, Maman Haeruman K, Lies Sulistiyowati, and Tomy Perdana. 2014. Determining agricultural superior commodity in the district of Sukabumi through a combination method of LQ, description scoring, and competitive analysis. Research Journal of Agriculture and Environmental Management. 3 (11): 599-604.

Sukmawani Reny, Maman Haeruman K, Lies Sulistiyowati, and Tomy Perdana. 2014. Papaya Development Model As A Competitive Local Superior Commodity. Jurnal Ekonomi Pembangunan. 15 (2): 128-140

Surakshitha. N. C, SharathKumar M and Vasanth Kumar. 2012. Urban and Peri-Urban Horticulture Issues in Horticultural Science. International Conference on Agriculture and Horticulture Science. September 14-15, 2012. Hyderabad International Convention Centre, India. http://dx.doi.org/10.4172/2168-9881.S1.004

Teixeira da Silva , Jaime A., Rashid, Zinia., Tan Nhut, Duong, Sivakumar, Dharini, Gera, Abed Gera., Souza, M.Teixeira., and P. F. Tennant. 2007. Papaya (Carica papaya L.) Biology and Biotechnology. Tree and Forestry Science and Biotechnology. 1(1): 47-73

Yao, S. 1997. Comparative Advantage and Crop Diversification: A Policy Analysis Matrix for Thai Agriculture. J. Agri. Econ 1(48): 211-222. 